\title{
Isparta ve Antalya İlerindeki Börülce (Vigna unguiculata L.) Tohumlarında Bazı Önemli Virüs Hastalıklarının Belirlenmesi
}

\author{
Handan ÇULAL KILIÇ iD 1*, Leyla Seda DOĞUTAŞ (D) 1, Ebru YILAN ID 1 \\ ${ }^{1}$ Isparta Uygulamalı Bilimler Üniversitesi, Ziraat Fakültesi, Bitki Koruma Bölümü, Isparta, Türkiye \\ Geliş Tarihi (Received): 22.02.2021, Kabul Tarihi (Accepted): 07.12.2021 \\ $\square$ Sorumlu Yazar (Corresponding author*): handankilic@isparta.edu.tr \\ (C) +902462146282 且 +902462146269
}

\section{ÖZ}

Bu çalışma Isparta ve Antalya illerinden toplanan börülce tohum örneklerinde Fasulye adi mozayik virüsü (Bean common mosaic virus: BCMV) ve Börülce hafif benek virüsü (Cowpea mild mottle virus: CpMMV)'nün belirlenmesi amacı ile 2016-2017 yıllarında yürütülmüştür. Tohum örnekleri BCMV ve CpMMV için Double Sandwich Enzyme Linked Immunosorbent Assay (DAS-ELISA) yöntemi ile analiz edilmiştir. Elde edilen sonuçlara göre tohum örneklerinin $B C M V$ ve CpMMV ile enfekteli olduğu belirlenmiş ve börülce tohum örneklerinde BCMV ve CpMMV etmenlerinin bulunma oranlarının sırasıyla \%22.22 ve \%11.11 olduğu saptanmıştır. Örneklerin sadece 2 adetinde \%2.22 oranında her iki virüsün karışık enfeksiyonu tespit edilmiştir. Bu çalışma ile Türkiye'de CpMMV etmeni börülcede serolojik olarak ilk kez belirlenmiştir.

Keywords: BCMV, börülce, CpMMV, DAS-ELISA

\section{Determination of Some Important Viruses in Cowpea (Vigna unguiculata L.) Seeds from Isparta and Antalya Provinces}

\begin{abstract}
This study was carried out to detect the presence of seed borne viruses in cowpea seeds collected from Isparta and Antalya provinces during 2016-2017. The seed samples were tested by Double Sandwich Enzyme Linked Immunosorbent Assay (DAS-ELISA) for Bean common mosaic virus (BCMV) and Cowpea mild mottle virus (CpMMV). Based on the results, the seed samples were infected with BCMV and CpMMV. Infection ratio for BCMV and CpMMV was determined as $22.22 \%$ and $11.11 \%$ respectively. The mixed infection of both viruses with a rate of $2.22 \%$ was detected in only two of the samples tested. Our knowledge CpMMV was firstly reported at cowpea plants in Turkey.
\end{abstract}

Anahtar Kelimeler: BCMV, cowpea, CpMMV, DAS-ELISA

\section{GíRiş}

Fabaceae familyası içerisinde yer alan baklagiller, insan beslenmesinde çok önemli yer tutmaktadır., Dünyada ve Türkiye'de tahıllardan sonra en fazla yemeklik baklagillerin üretimi yapılmaktadır. Baklagiller tek yıllık olup bitkisel proteinin ana kaynağı durumundadırlar. Yemeklik dane baklagillerinin 12000 türü bulunmakta ve bunların 200'ünün tarımı yapılmaktadır (Gülümser, 2016).

Baklagillerin, bitkisel protein bakımından beslenmede önemli olmalarının yanısıra, Rhizobium bakterileri aracılığı ile havadaki serbest azotu toprağa bağlamaları bu bitkilerin önemini daha da artırmaktadır (Şehirali, 1988). 
Ülkemizde 735 bin hektar alanda yaklaşık 1 milyon ton baklagil üretimi yapılmaktadır (Gülümser, 2016). Yemeklik dane baklagiller içerisinde yer alan börülcenin kültüre alınan türü Vigna unguiculata L.'dır (Kısa, 2010). Börülce, yeşil sebze ve kuru dane olarak tüketilmektedir. Ayrıca hayvan beslenmesinde de yem bitkisi olarak kullanılan bir bitkidir (Şehirali, 1988).

Dünyada en fazla Afrika ve Asya ülkelerinde börülce üretimi yapılmaktadır. Ülkemizde ise börülce; Marmara, Akdeniz ve Ege Bölgelerinde yoğun olarak yetiştirilmektedir (Huang ve Bie, 2010; TUIK, 2018).

Ülkemizde 21.612 dekar alanda 18.043 ton taze; 14.129 dekar alanda 1511 ton kuru dane üretimi yapılmaktadır. Isparta ilinde 192 dekar alanda 96 ton taze, 1500 dekar alanda 135 ton kuru börülce üretimi yapılmaktadır. Antalya ilinde ise; 838 dekar alanda 597 ton taze börülce üretimi yapılmaktadır (TUIK, 2018).

Börülce bitkisi içerdiği yüksek protein miktarı sebebi ile virüs hastalıklarına karşı son derece hassastır ve çok sayıda viral etmen börülcede enfeksiyon gerçekleştirebilmektedir (Hughes ve Shoyinka, 2003). Dünyada börülcede yaygın olarak enfeksiyona neden olan 140'dan fazla virüs olduğu ve bunlardan en az 15 tanesinin tohumla taşındığı bildirilmiştir (Mali ve Thottappilly, 1986). En önemli tohum kaynaklı virüsler arasında; Fasulye adi mozayik virüsü (Bean common mosaic virus: $\mathrm{BCMV}$ ), Börülce hafif benek virüsü (Cowpea mild mottle virus : CpMMV); Hıyar mozaik virüsü (Cucumber mosaic virus: CMV), Soya fasulyesi mozayik virüsü (Soybean mosaic virus: SBMV) olarak belirtilmiştir (Salem ve ark., 2010).

Etkin bir mücadelenin olmaması nedeni ile önemli bir yere sahip olan virüsler, enfekteli tohumlar ile yıldan yıla, yıl içinde de vektörlerle geniş alanlara yayılmaktadırlar (Yılmaz ve ark., 1995). Bu sebeple börülce yetiştiriciliğinde kullanılan tohumların virüs hastalıkları bakımından incelenmesi önem arz etmektedir.

Bu çalışmada Isparta ve Antalya illerinden toplanmış börülce tohum örneklerinde tohumla taşınan BCMV ve CpMMV etmenleri tespit edilmişlerdir.

\section{MATERYAL VE YÖNTEM}

Çalışmada Isparta ve Antalya ili börülce üretim alanları ile üretici pazarlardan temin edilen 90 adet tohum örneği kullanılmıştır. Börülce tohumları Isparta Uygulamalı Bilimler Üniversitesi, Ziraat Fakültesi, Bitki Koruma Bölümü'ne ait büyütme odalarında kontrollü şartlarda her örnekten yaklaşık 50 adet tohum seçilerek çimlendirilmeye bırakılmıştır (Şekil 1). Çimlenen bitkilerden 3-4 yapraklı dönemde örnekler alınmış ve DASELISA çalışmalarında kullanılmak üzere $-20^{\circ} \mathrm{C}$ derin dondurucuda muhafaza edilmişlerdir.

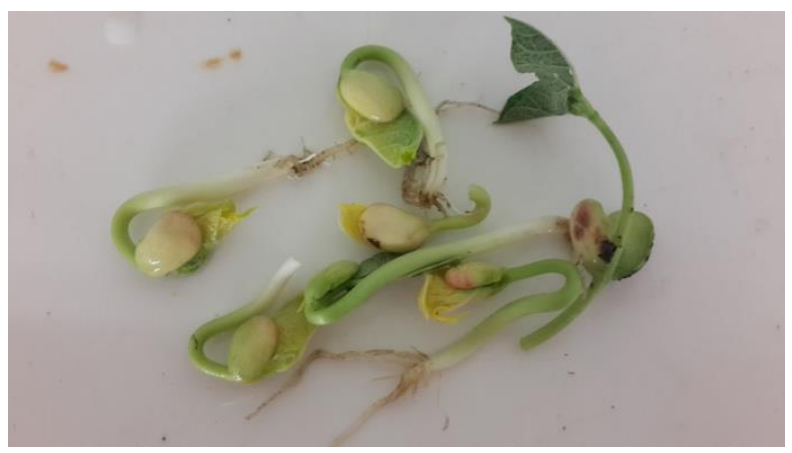

Şekil 1. Çimlenen börülce tohumları

Çalışmada; börülce tohumlarında BCMV ve CpMMV gibi bulunması muhtemel virüslerin belirlenmesi amacı ile börülce tohum örnekleri DAS-ELISA testine tabi tutulmuştur. Poliklonal antiserumlar, negatif ve pozitif kontroller Loewe (Biochemica, Germany)'den sağlanmıştır.

Yöntem üretici firmanın önerileri doğrultusunda gerçekleşmiştir. Sırası ile;

- ELISA pleytleri öncelikle 1:1000 oranında seyreltilen antikorlardan 200'er $\mu$ l olacak şekilde çukurlara ilave edilerek kaplanmış ve $37^{\circ} \mathrm{C}$ 'de 4 saat süre ile inbübatörde inkübe edilmiştir. Sonrasında pleytler boşaltılarak, yıkama tampon solüsyonu ile $3 \mathrm{kez}$ yıkanmıştır.

- Tohumlardan elde edilen fidelerden alınan yapraklar örnek tampon solüsyonunda $1 \mathrm{gr}$ yaprak dokusu başına 5 mlt olacak şekilde homojenize edilmiş ve pleytlerin her bir çukuruna 200 'er $\mu$ l olacak şekilde ilave edilmiş $+4^{\circ} \mathrm{C}$ 'de tüm gece bekletilmiş ve ertesi gün yıkama tampon solüsyonu ile $3 \mathrm{kez}$ yıkanmıştır.

- Konjugat tampon solüsyonunda 1:1000 oranında seyreltilen alkalin fosfataz enzimi ile işaretli virüse özgü antikordan 200'er $\mu$ l pleytin her bir çukuruna ilave edilmiştir. Pleytler 37 ${ }^{\circ} \mathrm{C}$ 'de inkübatörde 4 saat inkubasyona bırakılmıştır. Süre sonunda pleytler yıkama tampon solüsyonu ile yıkanmıştır.

- Sonrasında P-nitrofenil-fosfat substrat konsantrasyonunda sulandırıldıktan sonra pleytin çukurlarına 200'er $\mu$ l ilave edilmiştir. Pleytler 
oda sıcaklığında 60-120 dakika inkübasyona bırakılmıştır.

Sonuçlar ELISA okuyucusunda (Versamax) $405 \mathrm{~nm}$ dalga boyunda değerlendirilmiştir. Negatif kontrolün absorbans değerinin en az iki katı ve üzerinde absorbans değeri veren örnekler pozitif olarak kabul edilmiştir (Çulal-Kılıç ve ark., 2015).

\section{BULGULAR VE TARTIŞMA}

Araştırma kapsamında Isparta ve Antalya illerinden toplanan börülce tohumlarında yapılan görsel incelemelerde bazı tohumlarda; tohum büyüklüğünde azalma, tohum renginde değişiklik, anormal tohum oluşumu, buruşukluk, tohum üzerinde beneklenme gibi simptomların olduğu gözlemlenmiştir (Şekil 2).

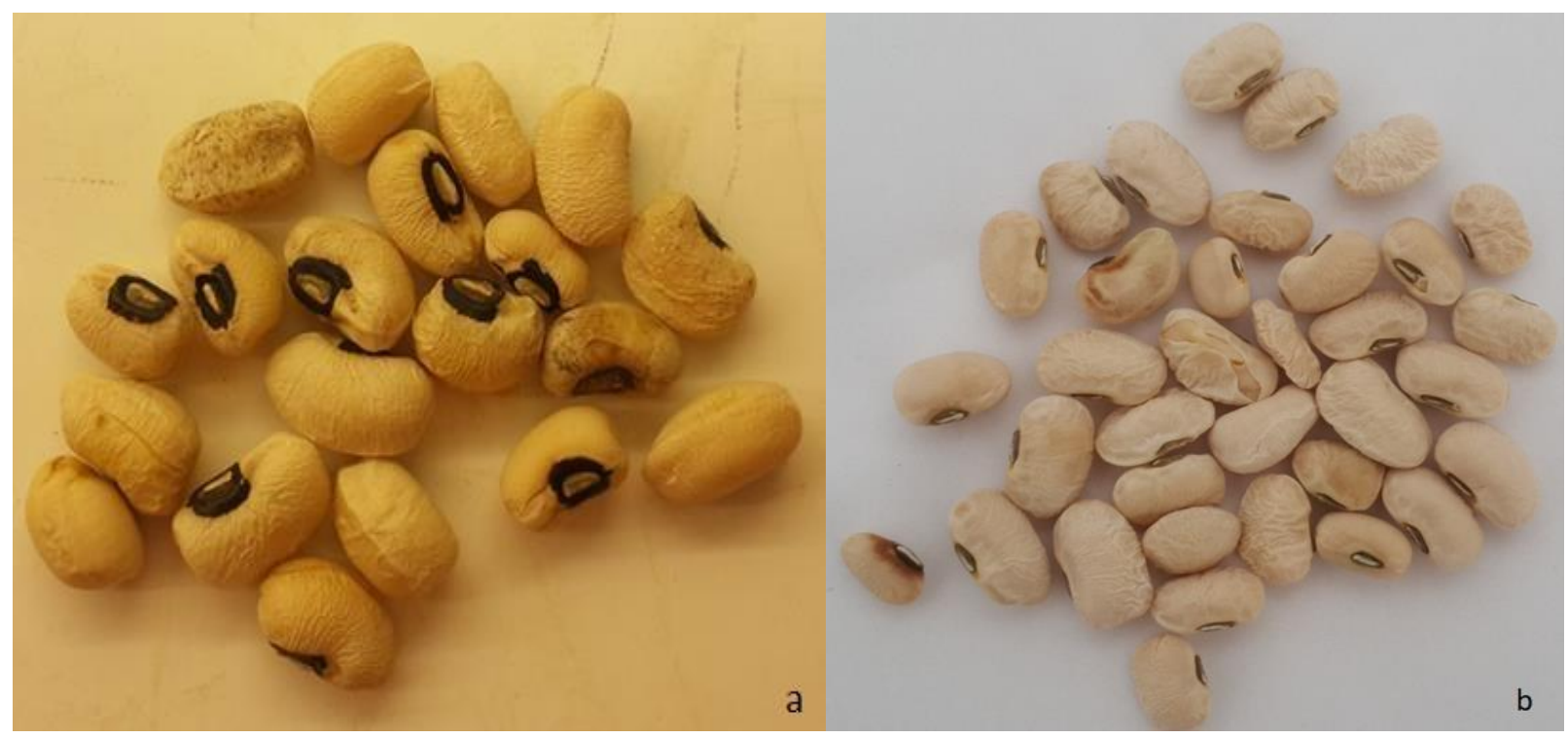

Şekil 2. Börülce tohumlarında görülen simptomlar

Börülce tohumlarının kontrollü şartlarda çimlendirilmesi sonucu gelişen bitkilerin bir kısmında, bitkinin yapraklarında kıvrılma, deformasyon, kabarcıklanma, damar çekilmesi gibi simptomlar gözlemlenmiştir (Şekil 3).

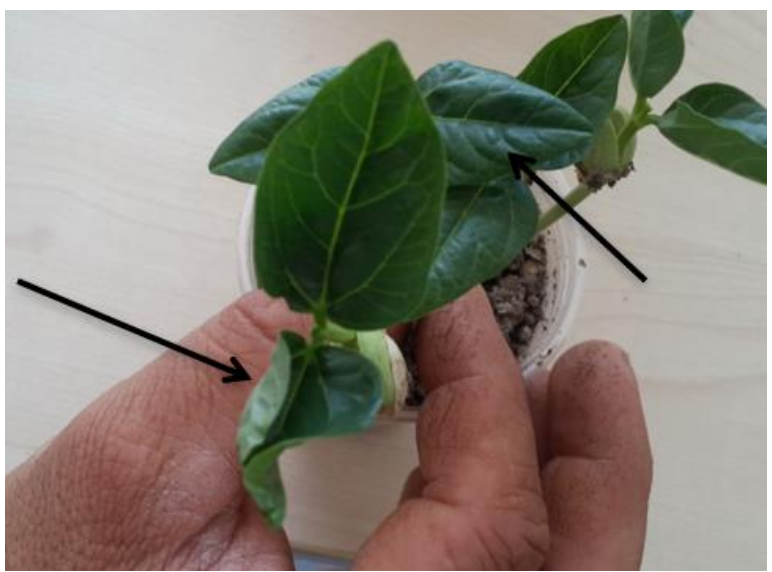

Şekil 3. Börülce tohumlarının çimlenmesi sonucunda fidelerde gelişen simptomlar
Isparta ve Antalya illerinden toplanan örneklerin DASELISA yöntemi ile testlenmesi sonucunda 90 adet örneğin 32'sinin bir veya birden fazla virüsle enfekteli olduğu ortaya konulmuştur (Tablo 1).

Test edilen örneklerin;

\% 22.22 (20 örnek)'sinde BCMV,

$\% 11.11$ (10 örnek)'inde CpMMV ve

\% 2.22 (2 örnek)'sin de BCMV +CpMMV ile enfekteli olduğu belirlenmiştir.

DAS-ELISA testi sonuçlarına göre; Isparta ilinde BCMV'nin enfeksiyon oranı \%23.40 iken Antalya'da bu oran \%20.93 olarak belirlenmiştir. CpMMV'nin ise Isparta'daki enfeksiyon oranı \%19.15; Antalya'da ise \%2.33'dür. BCMV+CpMMV karışık enfeksiyonuna sadece Isparta'da rastlanmış ve enfeksiyon oranı $\% 4.26$ olarak tespit edilmiştir.

Yapılan bu çalışmada börülce tohum örneklerinde saptanan BCMV ve CpMMV baklagillerde verim kaybına 
Isparta ve Antalya İllerindeki Börülce (Vigna unguiculata L.) Tohumlarında Bazı Önemli Virüs Hastalıklarının Belirlenmesi

yol açan en önemli viral etmenlerin başında gelmektedir (Salem ve ark., 2010). Dünyada börülce üretim alanlarında ciddi verim kaybına yol açan ve tohumlarla taşınan virüslerle ilgili çok sayıda çalışma mevcuttur (Bariana ve ark., 1994, Hao ve ark., 2003).

Tablo 1. Isparta ve Antalya illeri'nden toplanan börülce tohumlarında BCMV ce CpMMV etmenlerinin tespit oranları

\begin{tabular}{|c|c|c|c|c|c|c|c|}
\hline $\begin{array}{c}\text { Örnek Alı- } \\
\text { nan Yer }\end{array}$ & $\begin{array}{c}\text { Toplam } \\
\text { Örnek } \\
\text { Sayısı }\end{array}$ & $\begin{array}{c}\text { BCMV ile } \\
\text { Enfekteli } \\
\text { Örnek Sa- } \\
\text { yısı }\end{array}$ & $\begin{array}{c}\text { BCMV \% } \\
\text { Hastalık } \\
\text { Oranı }\end{array}$ & $\begin{array}{c}\text { CpMMV } \\
\text { ile Enfek- } \\
\text { teli Örnek } \\
\text { Sayısı }\end{array}$ & $\begin{array}{c}\text { CpMMV \% } \\
\text { Hastalık } \\
\text { Oranı }\end{array}$ & $\begin{array}{c}\text { BCMV+ } \\
\text { CpMMV ile } \\
\text { Enfekteli } \\
\text { Ornek Sa- } \\
\text { yısı }\end{array}$ & $\begin{array}{c}\text { BCMV+ } \\
\text { CpMMV } \\
\% \text { Hastalık } \\
\text { Oranı }\end{array}$ \\
\hline ISPARTA & 47 & 11 & 23.40 & 9 & 19.15 & 2 & 4.26 \\
\hline ANTALYA & 43 & 9 & 20.93 & 1 & 2.33 & 0 & 0 \\
\hline Toplam & $\mathbf{9 0}$ & $\mathbf{2 0}$ & $\mathbf{2 2 . 2 2}$ & $\mathbf{1 0}$ & $\mathbf{1 1 . 1 1}$ & $\mathbf{2}$ & $\mathbf{2 . 2 2}$ \\
\hline
\end{tabular}

Abdullahi ve ark., (2001) Afrika'da yaptıkları çalışmada CMV'nin börülce bitkisinde tohumla taşınma oranının \%30'lara kadar çıkabildiğini serolojik ve moleküler yöntemlerle ortaya koymuşlardır.

Ojuederie ve ark., (2009) Nijerya'da yaptıkları çalışmada börülce tohumlarında, CMV, Cowpea aphid borne mosaic virus, Cowpea yellow mosaic virus ve Southern bean mosaic virus'unun varlığını ortaya koymak için ELISA yöntemini kullanmışlar ve tohum örneklerinde en yaygın virüsün Cowpea aphid borne mosaic virus olduğunu belirtmişlerdir.

Ülkemizde, Çukurova bölgesinde fasulye ve börülce tohumlarında Börülce afit kökenli mozayik virüsü (Cowpea aphid borne mosaic virus) ELISA yöntemi ile saptanmıştır.

Ege bölgesinde yapılan farklı bir çalışmada fasulye, soya fasulyesi ve börülce tohumlarında sekiz farklı virüsün varlığı araştırımıştır. Tohum örneklerinde SBMV, Bezelye tohumla taşınan mozayik virüsü (Pea seed-borne mosaic potyvirus: PsbMV), BCMV, CABMV ve CMV tespit edilmiştir (Fidan ve Yorgancı, 1990).

Paylan ve Erkan (2013)'ın aynı bölgede sebze tohumları ile ilgili yaptıkları çalışmada 10 börülce tohumunun yalnızca 1 tanesinde CMV enfeksiyonu saptanmıştır.

BCMV özellikle fasulyede çok yüksek oranda (\%83) tohumla taşınmaktadır. Bu taşınma oranı bitki çeşidine ve enfeksiyon zamanına bağlı olarak değişebilmektedir (Omar ve ark., 1985). Habib ve ark. (1981); BCMV'nin tohumlarda buruşmalara, tohum sayısında azalmaya, anormal tohum oluşumuna neden olduğunu bildirmişlerdir. Yapılan bu çalışmada da börülce tohum örneklerini gözlemlediğimizde; tohum büyüklüğünde azalma, deformasyon, lekelenme ve buruşuk dane oluşumu gibi simptomlara rastlanmıştır. BCMV tohumla taşınmasının yanında yaprakbitleri ile, CpMMV ise beyaz sineklerle ve mekanik inokulasyonla taşınabilmektedir (Tavasoli ve ark., 2007).

\section{SONUÇ}

Virüslerin en önemli taşınma ve yayılma yollarından birisi tohumlardır. Bu sebeple börülce üretim alanlarında sorun olan bu BCMV ve CpMMV'nin kontrolünde sağlıklı tohum kullanılması son derece önemlidir. Kimyasal mücadelesi bulunmayan bu virüs hastalıkları ile etkili bir mücadele yapılabilmesi için öncelikle virüslerin belirlenmesi gerekmektedir.

Yapılan bu çalışma ile Isparta ve Antalya ili börülce tohumlarındaki BCMV ve CpMMV'nin varlığı DAS-ELISA yöntemi ile belirlenmiştir. Daha önce Isparta ili börülce tohumlarında SMV'nin varlığı ortaya konulmuştur (Çulal-Kılıç ve ark., 2020).

Araştırma, adı geçen bölgelerde börülce tohumlarında BCMV ve CpMMV'nin varlığını serolojik olarak ortaya koyan ilk çalışmadır. Ayrıca bu çalışma ile ülkemizdeki börülce tohumlarında CpMMV'nin varlığı ilk kez saptanmıştır.

Bundan sonraki yürütülecek olan çalışmalarda bölgede enfeksiyon oluşturan farklı virüslerin örnek sayısı arttırılarak daha kapsamlı bir çalışma ile araştırılması gerekmektedir. 


\section{TEŞEKKÜR}

Bu çalışma 'TÜBITAK 2209 A-Üniversite Öğrencileri Yurt İçi / Yurt Dışı Araştırma Projeleri Destekleme Programı' kapsamında desteklenmiştir. Maddi olanak sağlayan TÜBITAK'a teşekkür ederiz.

\section{KAYNAKLAR}

Abdullahi, I., Ikotun, T., Winter, S., Thottappilly, G., Atiri, G.I. (2001). Investigation on seed transmission of Cucumber mosaic virus in cowpea. African Crop Science Journal 9(4): 677-684.

Bariana, H.S., Shannon, A.L., Chu, P.W.G., Waterhouse, P.M. (1994). Detection of five seedborne legume viruses in one sensitive multiplex polymerase chain reaction test. Phytopathology 84: 1201-1205.

Çulal-Kılıç, H., Yardımcı, N., Açıkyürek, S., Uzal, A. (2015). Detection of BCMV, AMV and CMV by DAS-ELISA and Immunocapture-RT-PCR in bean growing areas in The West Mediterranean Region, Turkey. Fresenius Environmental Bulletin 24(5): 1752-1756.

Çulal-Kılıç, H., Özdoğan, H.M., Vural, M.C. (2020). Isparta ili börülce tohumlarında Soybean Mosaic Virus. Fen ve matematik bilimlerinde akademik çalışmalar. III. Bölüm, Livre De Lyon Basımevi, Fransa, 53-60.

Fidan, U., Yorgancı, U. (1990). Investigation on the detection and seed transmission of the virus diseases occuring on pulse crops in Aegean Region. Journal of Turkish Phytopathology 19(1): 1-5.

Gülümser, A. (2016). Dünyada ve Türkiye'de yemeklik dane baklagillerin durumu. Tarla Bitkileri Merkez Araştırma Enstitüsü Dergisi, 25 (Özel sayı-1): 292-298

Habib, S. A., El-Atta, O.K., El-Hammady, M., Awad, M. (1981). Interaction between Bean common mosaic virus and Bean yellow mosaic virus in relation to morphological characters of bean plants. Ain Shams University, Faculty of Agriculture Research Bulletin 1606: 1-14.

Hao, N.B., Albrechtsen, S.E., Nicolaisen, M. (2003). Detection and identification of the blackeye cowpea mosaic strain of Bean common mosaic virus in seeds of Vigna unguiculata spp. from North Vietnam. Australasian Plant Pathology 32: 505-509.

Huang, X., Bie, Z. (2010). Cinnamic acid-inhibited ribulose1.5-bisphosphate carboxylase activitiy is mediated through decrease spermine and changes in the ratio of polamines in cowpea. Journal of Plant Physiology 167: 47-53.

Hughes, J.A., Shoyinka, S.A. (2003). Overview of viruses of legumes other than groundnut in Africa," in Plant Virology in Sub-Sahara Africa, Hughes, J.A. and Odu J. (eds.), Proceedings of a conference organized by IITA Ibadan, Nigeria, International Institute of Tropical Agriculture, 553-568.

Kısa, D. (2010). Tuz stresinin börülce (Vigna unguiculata L. ) yağ asiti içeriğine etkisinin araştırılması. Gaziosman paşa Üniversitesi, Fen Bilimleri Enstitüsü, Biyoloji Anabilim Dalı. Yüksek Lisans Tezi, 69s.

Mali, V.R., Thottappilly, G. (1986). Virus diseases of cowpea in the tropics. In Review of tropical plant diseases, Raychsudhri, S.P. Verma, J.P. (eds.), Today and Tomorrow Publishers, New Delhi, India.

Ojuederie, O.B., Odu, B.O., Ilori, C.O. (2009). Serological detection of seed borne viruses in cowpea regenerated germplasm using protein A sandwich enzyme linked immunorsorbent assay. African Crop Science Journal, 17(3): $125-132$.

Omar, R.A., Mehiar, F.F., Zayed, E.A., Deit, A.A. (1985). Biological studies onsome seed-borne viruses and their effect on vegetative growth and yield component of the host plant. Acta Phytopathologica Acadiae Scientiarum Hungaricae, 20(3): 80-85.

Paylan, I.C., Erkan, S. (2013.) Bazı Sebze tohumlarındaki viral etmenlerin saptanması ve yaygınlık oranlarının belirlenmesi. Ege Üniversitesi, Ziraat Fakültesi Dergisi, 50(3): 231-240.

Salem, N.M., Ehlers, J.D., Roberts, P.A., Ng, J.C.K. (2010). Biological and molecular diagnosis of seedborne viruses in cowpea germplasm of geographically diverse sub-Saharan Origins. Plant Pathology 59: 773-784.

Şehirali, S. (1988). Yemeklik Dane Baklagiller, Ankara Üniversitesi Ziraat Fakültesi Yayınları, Ankara.

Tavasoli, M., Shahraeen, N., Ghorbani, Sh., Hashemi, S.H. (2007). Identification of cowpea mild mottle virusCPMMV in soybean from Iran. Proceedings of the $4^{\text {th }}$ Iranian Virology Congress: Medical University of Tehran, Iran, 342.

TUIK (2018). Bitkisel Üretim İstatistikleri. http://www.tuik.gov.tr (Erişim Tarihi: 22.05.2018).

Yılmaz, M.A., Baloğlu, S., Özaslan, M., Güldür, M.E. (1995). GAP bölgesinde kültür bitkilerinde belirlenen virüsler. GAP Bölgesi Bitki Koruma Sorunları ve Çözüm Önerileri Sempozyumu: 27-29 Nisan, 1995, Şanlıurfa, Türkiye, Kongre Kitabı, 241- 250.

Yılmaz M.A., Özaslan, D. (1989). Determination of cowpea aphid borne mosaic virus by enzyme linked immunosorbent assay on cowpea and bean seeds. Doğa, Türk Tarım ve Ormancılık Dergisi, 13(3a): 870-873. 